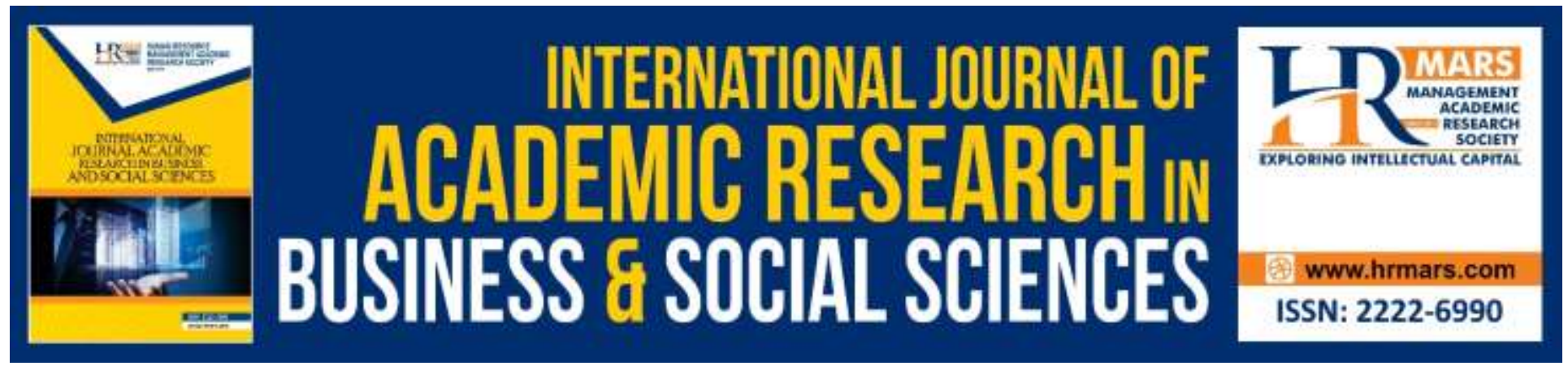

\title{
Children and Youth Leadership for Raising Awareness, Empowerment, Active Citizenship, and Wellbeing
}

\author{
Xhimi Hysa, Alberto Bilotta, Anastas Biqiku, Mario Calabrese
}

To Link this Article: http://dx.doi.org/10.6007/IJARBSS/v9-i11/6642

DOI: 10.6007/IJARBSS/v9-i11/6642

Received: 28 October 2019, Revised: 13 November 2019, Accepted: 20 November 2019

Published Online: 30 November 2019

In-Text Citation: (Hysa, Bilotta, Biqiku, \& Calabrese, 2019)

To Cite this Article: Hysa, X., Bilotta, A., Biqiku, A., \& Calabrese, M. (2019). Children and youth leadership for raising awareness, empowerment, active citizenship, and wellbeing. International Journal of Academic Research in Business and Social Sciences, 9(11), 1128-1147.

\section{Copyright: (C) 2019 The Author(s)}

Published by Human Resource Management Academic Research Society (www.hrmars.com)

This article is published under the Creative Commons Attribution (CC BY 4.0) license. Anyone may reproduce, distribute, translate and create derivative works of this article (for both commercial and non-commercial purposes), subject to full attribution to the original publication and authors. The full terms of this license may be seen at: http://creativecommons.org/licences/by/4.0/legalcode

Vol. 9, No. 11, 2019, Pg. 1128 - 1147

Full Terms \& Conditions of access and use can be found at http://hrmars.com/index.php/pages/detail/publication-ethics 


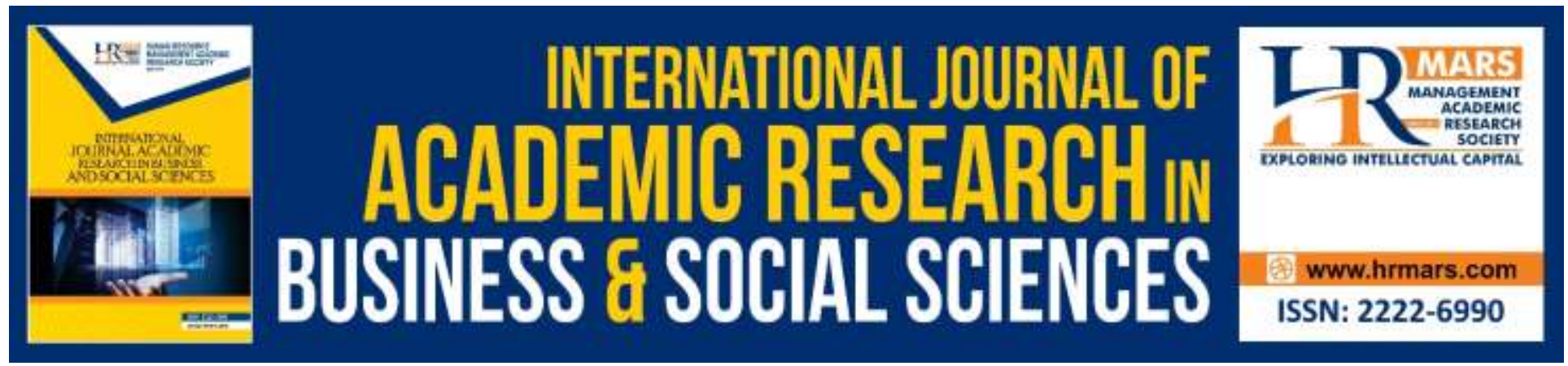

\title{
Children and Youth Leadership for raising Awareness, Empowerment, Active Citizenship, and Wellbeing
}

\author{
Xhimi Hysa \\ Department of Business Administration, Epoka University, A: Rruga Tirane-Rinas Km 12, 1032, \\ Vore/Tirane, Albania \\ Email: xhhysa@epoka.edu.al \\ Alberto Bilotta \\ Department of Management, Sapienza University of Rome, A: Via del Castro Laurenziano, 9, \\ 00161 Roma, Italy \\ Email: alberto.bilotta@uniroma1.it
}

\begin{abstract}
Anastas Biqiku
Sponsorship Department, World Vision Albania, A: Rruga "Skënderbej”, Ndërtesa Gurten, Kati 2, Tirana, Albania

Email: anastas_biqiku@wvi.org

Mario Calabrese

Department of Management, Sapienza University of Rome, A: Via del Castro Laurenziano, 9, 00161 Roma, Italy

Email: mario.calabrese@uniroma1.it
\end{abstract}

\begin{abstract}
The purpose of this study is to explore children and youth leadership through the case study of World Vision Albania as an illustration or representative of different generations of nongovernmental organizations in the matter. More specifically, it considers the contribution of creating a space and opportunity to youth leadership development by raising the leadership awareness within youth potential, the meaning and understanding that children/youth have in terms of leadership and how leadership in children/youth connects to empowerment, active citizenship and wellbeing. The study explores the impact of the variety and diversity of World
\end{abstract}


Vision Albania as a non-governmental organization with regards to working with children and youth for nurturing their leadership potential with the purpose of transforming them into active citizens. Likewise, this research explores employees' perceptions in terms of leadership style while working with children. Methodologically, the case study approach is used in combination with questionnaires and Key Informant Interviews. Thus, for investigating the research questions through a case study method, this paper uses a combination of quantitative structured interviews with qualitative in-depth interviews. Findings show that most of youth do not consider leadership simply as a goal per se, but also as a mean for being active citizens. They see their own empowerment relevant not only for personal wellbeing but also for the wellbeing of others.

Keywords: Children and Youth Leadership, World Vision, Active Citizenship, Wellbeing, NonGovernmental Organization

\section{Introduction}

"We cannot always build the future for our youth, but we can build our youth for the future" Franklin D. Roosevelt

Children and youth Leadership is a sensitive topic in research since it deals with the development and empowerment of future generations from education perspective, health, social, etc. (Zimmerman and Parker, 2010; Jennings et al., 2006; Kress, 2006; Ricketts and Rudd, 2002; M'mbijiwe, Jagero, Mburugu, \& Barchok, 2018).

Despite of many interventions for improving youth leadership and children empowerment in many areas worldwide by international organizations and NGOs, still the scientific analysis (in the academic sense and beyond reports) is to be enlarged and enriched. In addition, in Albania - a developing country with many interventions by international organizations such as World Vision, United Nations, and others, aiming to improve the children and youth biological and emotional conditions and consequently to reinforce some positive leadership traits in children and youth academic research about youth leadership in general, and specifically from the perspective of NGOs, is almost absent.

For the above reasons, this research is an attempted answer to the present scientific and pragmatic needs. Thus, the topic is about youth leadership in the different generations of NGOs working with children, illustrated by World Vision Albania case study. World Vision Albania (WV Albania) is a child focused organization implementing different projects in the field of development throughout 11 area development programs. According to Korten's framework (Korten, 1987; Anghelache, Marinescu, Samson, 2018), World Vision represents per se different generations of NGOs, service delivery, catalyst, facilitator, and networking. This research aims at exploring through World Vision Albania case study child/youth leadership with regards to its approaches while working with children. Concretely, it explores the role of World Vision Albania as an NGO for providing spaces and opportunities for children and youth to discover and mature them in terms of leadership potential and in the same time grow in their awareness of the importance of being empowered and active citizens.

This paper quantifies also the impact of WV Albania with regards to working with children for nurturing their leadership potential with the purpose of transforming them into active citizens. 
In this process, staff perspectives are explored too in terms of leadership as they are important because they tend to leave determinant models to children. This research considers also whether NGOs working with children (illustrated by WV Albania, which to some degree reflects all generations of NGOs in terms of children and youth-care) tend to prefer a specific leadership model and lastly, whether children and especially youth consider their empowerment as leaders as important to their wellbeing. The above mentioned are explored through the following research questions:

- How the evolution of leadership theories has impacted the most recent generations of NGOs or vice versa?

- What is the leadership model required or preferred by people working in the different generations of NGOs (represented by WV)?

- How working with children has evolved in terms of nurturing their leadership potential in the different generations of WV or how the different generations of WV and their model reflect on working with children with regards to their leadership potential?

- What is the ecology of interventions which affects leadership potential in children? How child wellbeing does affects/influences children and youth leadership potential?

- How child group age makes a difference in terms of their empowerment for leadership and leadership?

- Is there a youth leadership model in NGOs working with children? Is there a key leadership skill NGOs focus on when working with children?

The expectations for this research were that NGOs provide very good spaces and opportunities for child/youth leadership and that the diversity of an NGO per se enhances contribution to child/youth leadership and their empowerment. More specifically the expectations were that: life skills programs are crucial to child/youth leadership development; leadership skills/models contribute significantly to child/youth empowerment; children and youth see their leadership potential as a mean to their empowerment for the benefit of the community; children and youth see their empowerment as essential part of their wellbeing; NGOs staff are more prone to the model of servant leadership; development approaches contribute to a certain kind of leadership behavior and model; working with children/youth has a tendency for staff to nurture on them a specific model of leadership.

\section{Literature Review}

Leadership is among those concepts that scholars and practitioners have attempted to define for more than a century without a universal consensus. Despite the multitude of ways in which leadership has been conceptualized it has four central components: (a) Leadership is a process, (b) leadership involves influence, (c) leadership occurs in groups, and (d) leadership involves common goals. Based on these components, the following definition of leadership is used in this study: "Leadership is a process whereby an individual influences a group of individuals to achieve a common goal." (Northouse, 2010, p.5). 
INTERNATIONAL JOURNAL OF ACADEMIC RESEARCH IN BUSINESS AND SOCIAL SCIENCES Vol. 9, No. 11, November, 2019, E-ISSN: 2222-6990 @ 2019 HRMARS

\section{Transformational leadership: Releasing the Power of Youth}

The most direct approach related with youth development and empowerment is the "transformational leadership", a term coined for first by Downton (1973). Then it was Burns (1978) to see the concept holistically as an important approach to leadership because of the impact leaders have on followers and vice versa. For Burns, leadership is quite different from power because it is inseparable from followers' needs. We could say that leader-follower is a "dancing relationship" with mutual inspiration like a circular feedback loop.

The present approach has vital implications in several contexts. For example, adolescents who perceive their parents exhibiting transformational leadership behaviors would themselves display these behaviors (Zacharatos, Barling, and Kelloway, 2000)

The components of transformational leadership are the idealized influence, inspirational motivation, intellectual stimulation, and individualized consideration (Bass and Avolio, 1994; Avolio, 1999).

With the idealized influence, it is generally meant the power of charisma which has been defined as the emotional component of leadership (Antonakis, 2012). From this standpoint, leaders are seen as role models or as people with whom to be identified. However, the charismatic power can be dangerous wen used to gain power first and to abuse it later (e.g. this is the case of many dictators). This is why, in the first conceptualizations of transformational leadership, which for many aspects coincided with charismatic leadership (House, 1976), this emerging approach was criticized and skeptically accepted, even by the same developers and advocates. For instance, Bass (1998) coined the term "pseudo-transformational leadership" leadership to define those leaders who are self-consumed, exploitive, and power oriented, with warped moral values (Bass and Riggio, 2006). So, when abused, the transformational leadership becomes personalized leadership, which focuses on the leader's own interests rather than on the interests of others (Bass and Steidlmeier, 1999). Therefore, the idea is that through the idealized influence and charisma you can transform others, but in both directions, positive and negative. This is why Peter Drucker (2001) emphasized that leadership is not about charisma; it is more banal than romantic. In essence, it is work, responsibility, and example. Consequently, the idealized influence becomes a relevant factor especially when it comes to idealize the future of children and youth.

The inspirational motivation as a second factor of $\mathrm{TL}$, is related with effective communication skills and persuasion, the definition and encouragement of achieving challenging goals, and with a shared vision. Through a clear and shared vision, people inside the organization feel empowered because they feel they are a significant construct of the organization (Bennis and Nanus, 1985). In terms of communication and action, leaders can motivate followers through persuasion. This can be summarized with Nelson Mandela's words: "It is wise to persuade people to do things and make them think it was their own idea". In this way, youth will be motivated to change positively, to work, and achieve challenging goals. The first positive results, like a butterfly effect, will induce them to repeat the experience by entering a virtuous cycle. Consequently, children and youth's self-confidence and self-efficacy will boost. 
The third factor or the intellectual stimulation includes leadership that stimulates followers to be creative and innovative and to challenge their own beliefs and values as well as those of the leader and the organization. This is a crucial factor in developing pupil's knowledge and critical thinking, creativity and innovation. Therefore, in children and youth leadership context, the intellectual stimulation is relevant in the education context. Today, teachers are not just packages of information to be conveyed to the pupils, but they are facilitators and life-guides that conveys to the students also values and schemes of behavior. Quoting James March (2003), "The critical concerns of leadership are not technical questions of management or power, they are fundamental issues of life".

The fourth factor or the individualized consideration, stands for leaders who provide a supportive climate in which they listen carefully to the individual needs of followers. This factor is strongly related with the diversity concept. In diversity terms, every individual is unique, since it has a unique personality and DNA. Consequently, everyone deserves a special treatment, by recognizing potential and limitations, for not mentioning all those cases in which individuals might have different abilities and need a very careful individualized consideration. For example, in classrooms might be present people of different ethnic origins, color, language, physical abilities, etc. In fact, in his Eupsychian Management (1965), Abraham Maslow contrasted the view of Douglas McGregor (1960) about his theories $X$ and $Y$, since McGregor concluded that at the end the Theory $Y$ (liberal style of leadership) was the best approach of managing people. Instead, for Maslow, there is not a "one best way", because everyone needs a special leading style. From the group perspective, diversity does not mean simply being different, but also similar and complementary. So, through the individualized consideration, it is not empowered only the individual, but by recognizing similar and complementary skills with others, the group is empowered as a whole.

\section{Servant Leadership: we are all Civil Servants}

Servant leadership is another approach strongly related with the present and future of children. It is related with the present because children figure out their role models based on the today's "servants" (e.g. parents, teachers, public servants, etc.). They receive from them affection, security, vision, love, information, orientation, etc. These models of serving children and society, shape the future of today's children that tomorrow become civil servants based on the acquired models. As parents shift the focus from themselves on their children, servant leaders place the good of followers over their own self-interests and emphasize followers' development (Hale \& Fields, 2007). An essential aspect of servant leadership is moral, because servant leaders in order to be role models for what they serve, they stress to demonstrate always relevant moral behaviors toward followers (Graham, 1991; Walumbwa, Hartnell, \& Oke, 2010).

Northouse (2013), the term "servant leadership" sounds like a paradox because the common perception of leadership does not coincide with leaders being servants and putting followers first. There is a mechanistic and linear cause-effect view in which leaders influence and servants follow. Therefore, the effort is to merge influence with service at the same time. But, how can a person be a leader and a servant at the same time? 
To these concerns, an answer was given by Robert Greenleaf $(1970,1972)$ when he ideated the concept of "servant leadership" while reading Herman Hesse's (1956) novel The Journey to the East. He stated that "[Servant leadership] begins with the natural feeling that one wants to serve, to serve first. Then conscious choice brings one to aspire to lead... The difference manifests itself in the care taken by the servant - first to make sure that other people's highest priority needs are being served. The best test . . is: do those served grow as persons; do they, while being served, become healthier, wiser, freer, more autonomous, more likely themselves to become servants? And, what is the effect on the least privileged in society; will they benefit, or, at least, will they not be further deprived?" (Greenleaf, 1970, p. 15).

For Greenleaf (1977), there are three categorical values of servant leadership: trust, appreciation of others, and empowerment. These values constitute the foundations of servant leadership and might be considered as the underlying factors that separate servant leadership from all other leadership types (Russell, 2001).

\section{Development Approaches for Nurturing Leadership in Children and Youth}

Because the skills-based leadership approach shifts from a focus on personality characteristics, which usually are viewed as innate and largely fixed, to an emphasis on skills and abilities that can be learned and developed, it is quite logical to consider youth leadership concept and the development and potential of leadership in children or their empowerment. At the end, the innate and maturing are closely related to childhood.

In fact, signs or indicators of leadership in children are seen as early as 6 months of age when children are placed in a constructed play situation with other infants who are the same age (Brooks \& Shaffer, 1937). According to Parten (1933, pp.1), "in the preschool age [children] begin to show consistent leadership styles; even at the preschool age there are two definite types of leaders: the 'diplomat' and the 'bully'. The former, by indirect suggestions, controls a large number of children; the latter employs brute force in 'bossing' the small group he has chosen for his 'gang'. Independent play is most characteristic of all ages but decreases in frequency as the children grow older. Sex differences in leadership are negligible. Leaders somewhat exceed nonleaders in intelligence".

There is a trend toward development of leadership as the school year advanced and per Hillman and Smith (1981), as childhood progresses leadership becomes more persistent, with the leader representing the values and the characteristics of the group. The leader must exhibit a common interest to the group and be superior in the traits that are imperative for the activities in which he leads. A leader's superiority, however, cannot be too great, for this would isolate the child, a phenomenon with children who have extremely high IQs.

Still, is it just about the development of their potential or their empowerment or a truly youth leadership? These are two different things which may depend on the child group age.

The Convention on the Rights of the Child (www.ohcr.org) defines a 'child' as a person below the age of 18. Several studies demonstrate that the quality of these years has a significant impact on leadership skills and behaviors in children. The quality of those years impacts the quality of future leaders that is inherently linked to child ecological system. The relational developmental 
systems theories stress the importance of the ecology and contexts. These theories have as a distinctive feature the presence of (relative) plasticity in human development. According to Lerner and Callina (2014, p.373), "Such plasticity reflects the potential for systematic change in individual $\leftrightarrow$ context relations, a potential that derives from connections between the individual and the multiple levels of his or her changing context". Bronfenbrenner developed the ecological systems theory to explain how everything in a child and the child's environment affects how a child grows and develops (Bronfenbrenner, 1977).

Various actors are part of the ecology of child development: civil society actors and more specifically NGOs working with children are among these actors and as a consequence they contribute to the quality of the childhood years and they influence leadership skills and behaviors in children. NGOs working with children do have an important role and they intervene through their strategies, approaches programs and modules in each of these systems.

For Mitlin, Hickey \& Bebbington (2007), the strength of development NGOs remains their potential role in construction and demonstrating alternatives to the status quo, which remains a need that has never been more pressing. NGOs exist as alternatives. In being non-governmental they constitute vehicles for people to participate in development and social change in ways that would not be possible through government programs.

For example, in the 80 s concepts such as participation, empowerment, gender and a range of people centered approaches were alternatives or considered as such. The development as empowerment approach (alternative development) began to emerge as a part of a new formula that attempted to link theory and practice, challenge top down development policies and engage usefully with relationships of power and inequality (Friedman, 1992).

Within some types of alternative development thinking, NGOs were also seen as being able to play roles in linking local action back into processes of national and structural change. For example, Korten (1987) argued that NGOs could contribute to empowerment within political processes which link grassroots initiatives, broader social movements and political organizations, so as to build what he termed "people centered development". This has contributed to the rise of the rights-based approach and as a consequence, the need to see people as citizens and rather than as passive beneficiaries of development. By the 90 s variants of these ideas about participation and empowerment began to enter the development stream; what has become as alternative development had by now become part of the mainstream. Thus, it may be that the capacity of NGOs to transcend categories and boundaries is one of the main keys of their powers (Lewis and Kanji, 2009)

Also, it is important to consider not only development models and approaches when working with children but also attitudes, values and capabilities of staff including managers and leaders. Being a good leader, it is not just about increasing effectiveness and efficiency in the company, business or NGO; in the case of NGOs working with children it's also about better outcomes for children overall through a daily positive example when working in the field with and for children.

Regarding World Vision Albania, it is an NGO operating in 11 Area Development Programs having as primary goal the sustained well-being of children within families and communities, especially the most vulnerable and fulfillment of their rights within families and communities. 
World Vision has a holistic understanding of fullness of life for all children and this means that in order for children and youth to thrive, they should enjoy good health, should be educated for life, should be spiritually mature, and should be cared for, protected and participating. World Vision project models (education, youth, child protection and other mini projects) are designed to contribute to one or more Child Well-being Outcomes prioritized through dialogue with communities and partners.

\section{Methodology}

Because this study investigates a contemporary phenomenon in its real-life context, where the complexity of binomial phenomenon-context and its necessity for exploration are high, then the most appropriate investigative research strategy becomes the case study (Yin, 2014). In this research, the case study method is used in combination with questionnaires and Key Informant Interviews. Thus, for investigating the research questions through a case study method, this paper uses a combination of quantitative structured interviews with qualitative in-depth interviews. Besides secondary data (literature review overall, reports) primary data are collected through surveys, KIls and Focus Group Discussions. In addition, observations are used in real time events with children/youth and World Vision staff. The setting for this case study is the World Vision Albania.

More specifically the tools used for data gathering are two questionnaires, Key Informant Interviews with key people in the organization, and one observation in an impact club meeting of young people part of the World Vision youth program.

The first questionnaire was administered randomly to 200 participants from 12 years old to 18 years old from 4 different areas in Albania, areas which are part of World Vision areas development program, Elbasan, Tirana (Bathore area), Librazhd and Korca. The children/youth come from rural areas of these districts, except for Bathore that is an urban area.

The second questionnaire was administered randomly to 49 World Vision staff from different positions, in the National Office and in program areas.

Three key informant interviews were administered to three World Vision staff having relevant and important positions being very well positioned and experienced with regards to youth leadership within World Vision Albania.

In order to explore the research questions, the measured variables are: active citizenship; child/youth empowerment; leadership skills/models; child/youth leadership; NGO staff; child wellbeing; development approach; work with children/youth; the ecology of actors in child development; the meaning of being a leader; influence in leadership potential; key leadership skill; diversity of World Vision; contact with NGO.

In addition, combinations between variables are explored. The combinations explored are between question regarding meaning of leadership (question 2) and age of children (question 1); question regarding influence of different actors into leadership potential (question 3) and influence of the presence of an organization/structure/group on the awareness of leadership potential (question 5); question regarding influence of different activities into leadership potential (question 4) and influence of the presence of an organization/structure/group on the 
awareness of leadership potential (question 5); question regarding influence of different activities into leadership potential (question 4) and influence of the presence of an organization/structure/group on the awareness of leadership potential (question 6); question regarding influence of different actors into leadership potential (question 3 ) and influence of the diversity of WV in children development (question 9); question regarding the importance of gaining life skills in order to be a future good leader (question 13) and importance of being an active citizen (question 14); question regarding the contribution of empowerment as personal and potential leader in its own wellbeing (question 10) and contribution of empowerment as personal and potential leader in other's wellbeing (question 11); question on the importance of gaining life skills in order to be a future good leader (question 13) and influence of the diversity of WV in children development (question 9); question regarding the importance of being an active citizen (question 13) and influence of the diversity of WV in children development (question 9); question regarding influence of the diversity of WV in children development (question 9) and the influence of a WV staff regarding youth maturity and leadership potential (question 12).

A statistical program is used for analyzing data through cross tabulations, analyzing frequency and relationships mostly through Pearson Chi-Square test.

\section{Findings and Discussion}

After analyzing data from the survey with 200 children and 49 World Vision staff and the Key Informant Interviews with three World Vision staff, the following provides a summary of the findings by describing and interpreting the data, comparing findings with initial expectations.

For the question regarding meaning of leadership (question 2) and age of children (question 1), almost half of the youth have a group sense with a slight tendency of increase for children from 16-18 years old (the same applies for both genders). This is important as group notion is fundamental to leadership. Based on the Pearson Chi-Square, there is an insignificant relationship (.142) between question regarding meaning of leadership (question 1) and age of children. In one of the largest studies performed, Sessa et al., (2007) analyzed 79,866 direct report ratings of leaders using the Leadership Effectiveness Analysis instrument. Participants came from more than 6,000 North American companies in 23 industries across 48 states. Older leaders were rated as calmer and as using a more considered approach that draws on the skills and abilities of others. Younger leaders were rated as more energetic. They were also seen as focused on attaining short-term results and were more self-centered. This is an ulterior confirmation also of the common sense. However, data are missing on the relationship ageleadership in children and youth, and especially in their personal perception. In the present research the mentioned relationship is not significant.

For the question regarding influence of different actors into leadership potential (question 3) and influence of the presence of an organization/structure/group on the awareness of leadership potential (question 5), it should be noticed that inner circle refers to self and family, whereas outer circle refers to society, school organizations, etc.; when children have mentioned only the term "organization", this was classified as a separate answer. According to the analysis, it is quite 
impressive that out of 200 youth, 157 have answered that contact or presence of an organization/group/structure has influenced a lot in youth awareness on leadership potential. Since these youths have been involved in youth impact clubs, we can assume that they refer to WV presence or contact. This is also somewhat confirmed by the answers to the other questions regarding whether children/youth would have had other opportunities to leadership awareness raising if they have not been involved with World Vision or other organizations; in this case, 107 of them out of 200 responded "no". Based on the above data, we can say that most of them are aware of the importance of the ecology of actors in their leadership potential, inner circle (selfdevelopment, family) and outer circle (society, school organizations etc.). However, based on the Pearson Chi-Square there is no statistically significant relationship (.587) between both variables.

In regards to the combination of question referring the influence of different activities into leadership potential (question 4) and influence of the presence of an organization/structure/group on the awareness of leadership potential (question 6), the statistically significant relationship (.043) between the two variables shows and validates the importance of the presence of World Vision or other similar organizations working with children and of different trainings (including meetings with active participation and interaction) on raising the awareness of youth on their leadership potential. Most of youth have responded that trainings and active participation influence the greatest into their leadership potential. We can imply also that an emphasis is put on skill-based leadership, and youth tend to believe that personality is not a final determinant for being a future leader. This is a response of the famous question: "leaders are made or born?". At this point, leadership schools of thought are in contrast with each other. For some authors, leaders are born with specific qualities. This philosophy represents the trait approach to leadership. The trait approach, is one of the most appealing approaches of leadership emphasizing innate "great" qualities of leaders, differentiating them from followers (Bass, 1990). The major studies in this field in a chorological order have been conducted by Stogdill (1948, 1974), Mann (1959), Lord, DeVader \& Alliger (1986), Kircpatrick and Locke (1991) and Zaccaro, Kemp \& Bader (2004). On the other side, there other authors who believe that leadership is not trait-like but state-like, meaning that it can be cultivated by time (Northouse, 2013). Thus, leadership it is supposed to be a dynamic process between leaders and followers; it can be learned and observed in leader behaviors (Jago, 1982). The evidence of the present research confirms that leadership can be learned and developed, which makes leadership available to everyone.

For the blend of question regarding influence of different actors into leadership potential (question 3) and influence of the presence of an organization/structure/group on the awareness of leadership potential (question 6), the statistically significant relationship (.012) between the two variables shows again the importance of the presence of World Vision Albania or other similar organizations to the awareness of youth on the ecology of their development, at least when it comes to leadership potential.

Referring to the combination of question regarding influence of different actors into leadership potential (question 3) and influence of the diversity of WV in children development (question 9), the statistically significant relationship (.015) between the two variables shows again the 
influence of the diversity of World Vision Albania in what it offers as projects and approaches for children to understand that several actors are key players for their development and more specifically their leadership potential development. It is an interesting result that 45 of children - who have responded to question 9 related with the influence that the diversity of World Vision has on their development - have responded that the inner circle (self and family) influence them in their leadership potential. This result has a strong research backup based on diversity and inclusion in similar researches in Albania, especially in dealing with the empowerment of Roma and Egyptians (Hysa \& Titka, 2017a; 2017b).

Combination of question regarding the importance of gaining life skills in order to be a future good leader (question 13) and importance of being an active citizen (question 14), almost 180 out of 200 children have responded that it is very important or extremely important to gain life skills in order to become a good leader. This shows how important are the different modules and programs which emphasize the transmission of different life skills to children. Unfortunately, today there is a problem of simplicity explanations and hyper-specializations that means an exaggerated focus on competences (e.g. developing the application of knowledge more than the knowledge itself) (Morin, 2005). So, sometimes teachers are preoccupied to teach to the pupils only how they can survive in today's workplace. What to do when the workplace changes? Then, these students (now workers) face many difficulties of adaptation, especially in the actual global dynamic market. In other words, a financial manager must know very well its responsibilities, but he should not ignore the rest of the organization, because not everything is finance and numbers. Thus, a financial manager must know something about marketing, logistics, human resources, etc. According to Pascal, as cited in Morin (2005, p. 47), "[...] I hold it equally impossible to know the parts without knowing the whole and to know the whole without knowing the parts in detail". The superficiality is a great problem for the survivor of youth as viable systems. Given the present challenge of educating healthily children and youth, researchers have developed the so-called "T-shaped knowledge" based on the cycle resources-capabilities-competencies (Barile et al., 2015). In practice, when we refer to resources, we mean every type of resource that an individual possesses; for example, cognitive resources, material resources, physical resources, financial resources, etc. The combination of resources makes up a capability. The capability is a know how without purpose and context. It becomes competence when the capability is purposeful and contextualized. For instance, a book is a resource, knowledge is a capability, and the application of the acquired knowledge (through interactive learning and reflection) in the workplace (or a simulation of it) is a competence.

Regarding active citizenship behavior, also most of the children have responded that it is very important or extremely important to be active citizen. There is a statistically significant relationship (.000) between the two variables which shows the positive influence of life skills into active citizenship awareness raising. Also, which is very important, we may imply that leadership or good leadership is not considered as a goal per se but as a means for being an active citizen.

For the combination of question regarding the contribution of empowerment as personal and potential leader in its own wellbeing (question 10) and contribution of empowerment as personal and potential leader in other's wellbeing (question 11), there is a statistically significant 
relationship (.000) between the two variables. This is another important finding showing how much crucial is the empowerment of children and youth through life skills models and other interventions for their own wellbeing. In addition, children and youth consider their empowerment as closely linked to the wellbeing of others. This goes in the same direction with active citizenship which is oriented towards actions and commitments to others, for the benefit of others and society overall. Recent research on transformational and happiness at work, shows how transformational leadership and empowerment contributes to wellbeing through developing organizational learning capabilities as mediating variable (Salas-Vallina et al., 2017).

The combination of question regarding the importance of gaining life skills in order to be a future good leader (question 13) and influence of the diversity of WV in children development (question 9), shows a statistically significant relationship (.000) between the two variables emphasizing the impact of the diversity of World Vision in its projects and approaches in the importance of life skills when working with children and youth. This is an ulterior confirmation of the previous dyadic relationships (i.e. skills-leadership development; diversity-leadership development)

Combination of question regarding the importance of being an active citizen (question 13) and influence of the diversity of WV in children development (question 9), there is a statistically significant relationship (.000) between the two variables showing the impact of the diversity of World Vision in its projects, approaches in the importance of being active citizens. Again, this is an ulterior confirmation of previous relations. It is common sense that an active citizen has an orientation to diversity, since an effective active citizenship behavior, means approaching to others holistically by evaluating their needs, perceptions, emotions, personality, motives, etc. On the other side, it was stated before that diversity orientation contributes to leadership development.

Combination of question regarding influence of the diversity of WV in children development (question 9) and the influence of a WV staff regarding youth maturity and leadership potential (question 12), there is a statistically significant relationship (.000) between the two variables. If the correlation between age and leadership didn't show any significance in question 1, the present combination of questions 9 and 12 show that diversity is a very strong determinant for youth maturity and leadership potential. Thus, the meaning of youth maturity and leadership potential for this research were not related with age as much as they were related with diversity. Thus, youth maturity is not a matter of age, but a matter of learning and being part of a fertile environment.

Referring to the findings related to surveys with 49 WV staff, almost $70 \%$ of the staff answering the survey is female; positions of staff answering the survey are diverse, as displayed in the chart above. Concretely, $69.4 \%$ are females and $30.6 \%$ males. According to the job positions: officers (26.5\%), coordinators (22.4\%), development facilitators (20.4\%), managers (10.2\%), other (20.4 $\%)$. Based on the survey results, more than $50 \%$ of staff prefers the servant leadership style seconded mostly by transformational leadership style. Based on findings, it appears that these staff have been influenced almost equally (similar percentages) in preferring this model both by their colleagues and work with children. 
Regarding findings about Key Informant Interviews (KIIs) and further discussions, World Vision Albania is doing an admirable work when it comes to children and youth and their development and more specifically their leadership potential. What stands out is that World Vision in building leadership in children does not necessarily aim the elite or brilliant children but first of all and especially those most vulnerable living in poor and rural areas. As such World Vision Albania tackles an important issue as confirmed by numerous research findings which validate the close relationship between poverty and vulnerability (in a broader sense) with child development applied to each development stage within the ecology of child development.

Believing in the most vulnerable children opens a new perspective, a totally different perspective on their level of participation and leadership potential. It is very important that leadership modules, approaches and programs with these children be contextualized so that the "do not harm" principle applies, and that children/youth are not conveyed a biased concept on leadership and its uses. This remains a risk considering that adolescents face a range of developmental issues. However, based on surveys and KIIs most youth do not consider leadership a goal per se, on the contrary they consider it as a mean for being active citizens. This is confirmed also by the fact that they consider their own empowerment as important not only for their own wellbeing but also for the wellbeing of others. These two important elements indicate that the leadership nurtured on children and youth by World Vision Albania, is a value-based leadership oriented into the benefit of others, for the benefit of the community, the common good and not for personal benefits. This becomes significant given the political context of Albania and the lasting transition period which has seen emerging different leaders leaving to society not very good example of their leadership which in most cases has been self-oriented in the sense that they have served mostly their own interests.

As validated by the surveys, by working with children and youth and especially within youth program, World Vision provides very good spaces and opportunities for them to enhance their awareness on the meaning of leadership, on the importance of the environment they grow in, and the meaning of their ecology of development. In addition, to grow personally through life skills and active participation and interaction with each other within youth group; so, to put into practice the idea of being an active citizen serving the common good, the right causes in the service of the communities they live in. World Vision thus contributes to the quality of these crucial years for children and more specifically to the quality of future potential leaders.

Life skills stand out as very important for youth; based on the surveys and KIls and observation during a youth group meeting it appears that gaining life skills is necessary and crucial for becoming aware of leadership potential, growing personally and professionally. Most of all it appears crucial for being an active citizen which is the goal of youth program and is one of the main goals of the organization when working especially with youth, to make them active, empowered, raise their voice with confidence and challenge the system, what does not work, what is rotted and advocate for the fulfillment of their rights.

Thus, it appears that life skills, leadership and active citizenship are part of the same value chain and have a strong relationship and dependence with each other and the most important of all, based especially on the surveys, children appear to have grasped the essence, meaning 
that life skills and leadership are not goals per se but important means towards being empowered and active for the good of the society. Generating a critical mass of children and youth being active citizens is also important in order to bring tangible changes in the community. Again, life skills and leadership approaches are not a goal per se but very important means in empowering children to become active citizens serving the community, raising their voice against injustices. This element has the more weight considering the risks that may appear if programs, projects and approaches make of like skills and leadership goal per se. One of the main risks may be that in children may be nurtured a style of leadership which is self-oriented, not necessarily valuebased.

This value chain is what is aimed also with other projects, including the education ones. Whereas in the past school's structures if assessed against Hart's ladder of participation (Hart, $1992,2013)$ would have been in the tokenism stage, today having invested years in child wellbeing in working with the communities, supporting the model of Schools as a community center, working with different stakeholders in the field, we are no more in the tokenism stage but significant progress has been made towards the highest stage of Hart ladder which is child lead initiatives.

Thus, child lead initiatives stage is strongly connected with active citizenship and based on the surveys with children and youth appear to be in the highest level of Hart ladder of participation (i.e. young people lead and initiate action and share decisions).

Also, based on the survey there is no indication on whether the child group age makes a difference in terms of their empowerment for leadership, taking into account that the age ranges from 12 years old to 18 years old. However, referring to the question of whether there is a youth leadership model in NGOs working with children? (WV case) and a key leadership skill of NGOs when working with children, there is not a unique youth leadership model when working with children and youth including in the youth project.

Because World Vision as other NGOs working with children believe that every child is a potential leader this assumes first an understanding of leadership as a dynamic process available to everyone. Unlike personality traits, skills are competencies that people can learn or develop. Leadership is more state-like than trait-like.

Though it appears that a mix of leadership styles is nurtured to children and youth, which include, transformational leadership, servant and ethical leadership, within this space and opportunity created by organizations like World Vision, two important elements stand out as significantly influencing the way they see their leadership potential, empowerment and active citizenship: First, the diversity of World Vision in its projects, approaches, models used with children appears to be one factor of influence. The diversity of World Vision should be seen as representing its history and different generations of NGOs it embodies according to Korten's framework. Therefore, its diversity is an added value within the space and opportunity created for children and youth. Second, World Vision staff as very good examples to follow appears as another determinant. As mentioned in the survey with staff comments, World Vision staff tends to prefer and follow a mix of transformational, servant and ethical leadership. Working in 
development and with children focusing in bringing change in their lives and community they live in is probably a good explanation of this tendency.

Concluding, with regards to the impact of different projects and modules contributing to children and youth life skills and leadership potential, there is an important mutual positive influence between staff and children in terms of leadership model and style. This element should not be downplayed. Work with children and youth towards developing their leadership, empowering them, should not be considered as separate from other interventions in the broader ecology of child development. Also, work with parents and schools is very important if to optimize the impact with children in terms of leadership quality and inspiring them to be active citizens for serving the communities they live in, by increasing their personal and others' well-being.

\section{Conclusions and Implications}

Based on the findings, it was shown that almost half of the youth have a group sense with a slight tendency of increase for youth from 16-18 years old (the same applies for both genders). This major finding shows how youth give particular attention to team leadership. By having a group sense, it is not empowered only the individual, but by recognizing similar and complementary skills with others, the group is empowered as a whole. This find a literature support from the theory of transformational leadership (Bass and Avolio, 1994; Avolio, 1999), especially in the component "individualized consideration" (i.e. caring for others). Although local studies are missing (especially in the Western Balkans area), overseas studies have shown that older leaders were rated as calmer and as using a more considered approach that draws on the skills and abilities of others; younger leaders were rated as more energetic (Sessa et al., 2007). These insights unfold practical implications in terms of group dynamics, advising us to build teams with older and younger members in order to combine the patient approach of experience and the energized approach of innovation and creativity. However, the present study did not find any significant relationship between age and leadership in children and youth. Instead, it was very significant the influence of different activities into leadership potential of children and youth when mediated by relevant organizations or groups. The results were even stronger when the mediated organization stands for diversity. These results have strong practical implication because confirm that leadership can be learned and developed, which makes leadership available to everyone. In this way it is overcome the classical debate between trait approach and behavioral schools. Even concepts like optimism that once were considered trait, today it can be seen as an attitude. For example, from a positive psychological perspective the optimism can be learned (Seligman, 2006). In terms of the diversity influence of International Organizations among children and youth (especially the marginalized ones), there are local studies in the Western Balkans to support the results of this work (Hysa \& Titka, 2017a; 2017b). Another interesting significant finding was that of relating life skills with leadership skills or being an active citizen and being a good leader. James March (2003), in a documentary movie of Stanford Graduate Schools of Business, simultaneously shows the theoretical and practical implications of this result when he highlights the role of Don Quixote in leadership stating that "the critical 
INTERNATIONAL JOURNAL OF ACADEMIC RESEARCH IN BUSINESS AND SOCIAL SCIENCES

Vol. 9, No. 11, November, 2019, E-ISSN: 2222-6990 ㄷ 2019 HRMARS

concerns of leadership are not technical questions of management or power, they are fundamental issues of life".

\section{References}

Anghelache, C., Marinescu, A.-I., Samson, T. (2018). Theoretical Characteristics of the Purchasing Power Parity in the EU Context, International Journal of Academic Research in Accounting, Finance and Management Sciences 8 (2): 37-47.

Antonakis, J. (2012). Transformational and charismatic leadership. In D. V. Day \& J. Antonakis (Eds.), The nature of leadership, $2^{\text {nd }}$ ed. Thousand Oaks, CA: Sage.

Avolio, B. J. (1999). Full leadership development: Building the vital forces in organizations. Thousand Oaks, CA: Sage.

Barile, S., Saviano, M., \& Simone, C. (2015). Service economy, knowledge, and the need for Tshaped innovators. World Wide Web, 18(4), 1177-1197.

Bass, B. M. (1990). Bass and Stogdill's handbook of leadership: A survey of theory and research. New York: Free Press.

Bass, B. M. (1998). The ethics of transformational leadership. In J. Ciulla (Ed.), Ethics: The heart of leadership (pp. 169-192). Westport, CT: Praeger.

Bass, B. M., \& Avolio, B. J. (1994). Improving organizational effectiveness through transformational leadership. Thousand Oaks, CA: Sage.

Bass, B. M., \& Riggio, R. E. (2006). Transformational leadership (2nd ed.). Mahwah, NJ: Lawrence Erlbaum.

Bass, B. M., \& Steidlmeier, P. (1999). Ethics, character, and authentic transformational leadership. Leadership Quarterly, 10, 181-127.

Bennis, W. G., \& Nanus, B. (1985). Leaders: The strategies for taking charge. New York: Harper \& Row.

Bronfenbrenner. (1977). Toward an experimental ecology of human development. American Psychologist, 32(7), 513-531.

Brooks, F. D., \& Shaffer, L. F. (1937). Child psychology. Boston: Houghton Mifflin Company.

Burns, J. M. (1978). Leadership. New York: Harper \& Row.

Downton, J. V. (1973). Rebel leadership: Commitment and charisma in a revolutionary process. New York: Free Press.

Drucker, P. F. (2001). The Essential Drucker: The Best of Sixty Years of Peter Drucker's Essential Writings on Management. New York: HarperCollins Publishers.

Friedman, J. (1992). Empowerment: The Politics of Alternative Development. Wiley-Blackwell.

Graham, J. W. (1991). Servant leadership in organizations: Inspirational and moral. Leadership Quarterly, 2, 105-119.

Greenleaf, R. K. (1970). The servant as leader. Westfield, IN: The Greenleaf Center for Servant Leadership.

Greenleaf, R. K. (1972). The institution as servant. Westfield, IN: The Greenleaf Center for Servant Leadership. 
INTERNATIONAL JOURNAL OF ACADEMIC RESEARCH IN BUSINESS AND SOCIAL SCIENCES

Vol. 9, No. 11, November, 2019, E-ISSN: 2222-6990 @ 2019 HRMARS

Greenleaf, R. K. (1977). Servant leadership: A journey into the nature of legitimate power and greatness. New York: Paulist Press.

Hale, J. R., \& Fields, D. L. (2007). Exploring servant leadership across cultures: A study of followers in Ghana and the USA. Leadership, 3, 397-417.

Hart, R. (1992). Children's Participation from Tokenism to Citizenship. Innocenti Essays, Vol. 4. UNICEF.

Hart, R. A. (2013). Children's participation: The theory and practice of involving young citizens in community development and environmental care. Routledge.

Hesse, H. (1956). The journey to the East. London: P. Owen.

Hillman, S., \& Smith, G. (1981). Development of leadership capacities in children. The Elementary School Journal, 82(1), 59-65.

House, R. J. (1976). A theory of charismatic leadership. In J. G. Hunt \& L. L. Larson (Eds.), Leadership: The cutting edge (pp. 189-207). Carbondale: Southern Illinois University Press.

Hysa, X., \& Titka, M. (2017). Behavioral change training curriculum and manual for public servants. Tirana / Albania. https://doi.org/10.13140/RG.2.2.35117.59366

Hysa, X., \& Titka, M. (2017). ESERE Behavioral Change Model Changing Attitudes and Behaviors of Public Servants with Regards to Roma and Egyptians' Access to Public Services. Tirana / Albania. https://doi.org/10.13140/RG.2.2.21695.82085

Jago, A. G. (1982). Leadership: Perspectives in theory and research. Management Science, 28(3), 315-336.

Jennings, L. B., Parra-Medina, D. M., Hilfinger-Messias, D. K., \& McLoughlin, K. (2006). Toward a critical social theory of youth empowerment. Journal of Community Practice, 14(1-2), 3155.

Kirkpatrick, S. A., \& Locke, E. A. (1991). Leadership: Do traits matter? The Executive, 5, 48-60.

Korten, D. C. (1987). Third generation NGO strategies: A key to people-centered development. World development, 15, 145-159.

Kress, C. A. (2006). Youth leadership and youth development: Connections and questions. New Directions for Student Leadership, 2006 (109), 45-56.

Lerner, \& Callina, S. (2013). Relational Developmental Systems Theories and the Ecological Validity of Experimental Design. Human Development, Vol. 56 (No.6), 372-380.

Lewis, D., Kanji, N. (2009). Non-Governmental Organizations and Development. USA: Routledge.

Lord, R. G., DeVader, C. L., \& Alliger, G. M. (1986). A meta-analysis of the relation between personality traits and leadership perceptions: An application of validity generalization procedures. Journal of Applied Psychology, 71, 402-410.

M'mbijiwe, J. M., Jagero, N., Mburugu, B. M., \& Barchok, H. K. (2018). Relationship between Teacher Training Practices and Transition to Secondary School for Public Primary School Learners with Disabilities in Meru County, Kenya. International Journal of Academic Research in Progressive Education and Development, 7(2), 64-71.

Mann, R. D. (1959). A review of the relationship between personality and performance in small groups. Psychological Bulletin, 56, 241-270. 
INTERNATIONAL JOURNAL OF ACADEMIC RESEARCH IN BUSINESS AND SOCIAL SCIENCES

Vol. 9, No. 11, November, 2019, E-ISSN: 2222-6990 @ 2019 HRMARS

March J., Schecter S., (2003), Passion and Discipline: Don Quixote's Lessons for Leadership, Schecter Films \& Stanford Graduate School of Business.

Maslow, A. H. (1965). Eupsychian Management. Homewood, Illinois: Richard D. Irwin. Inc. and The.

McGregor, D. (1960). The Human Side of Enterprise. New York: McGraw-Hill.

Mitlin, D., Hickey, S., \& Bebbington, A. (2007). Reclaiming development? NGOs and the challenge of alternatives. World development, 35(10), 1699-1720.

Morin, E. (2005). Educate gli Educatori: Una riforma del pensiero per la democrazia cognitiva. Roma: EDUP.

Northouse, P. (2013). Leadership: theory and practice, $6^{\text {th }}$ ed. Sage.

Northouse, P. G. (2010). Leadership: Theory and practice, $6^{\text {th }}$ ed. USA: Sage.

Parten, M. B. (1933). Leadership among preschool children. The Journal of Abnormal and Social Psychology, Vol 27(4), 430-440.

Ricketts, J. C., \& Rudd, R. D. (2002). A comprehensive leadership education model to train, teach, and develop leadership in youth. Journal of Career and Technical Education, 19(1), 7-17.

Russell. (2001). The role of values in servant leadership. Leadership \& Organization Development Journal. 22 (2), 76-84.

Salas-Vallina, A., Lopez-Cabrales, A., Alegre, J., \& Fernandez, R. (2017). On the road to happiness at work (HAW): Transformational leadership and organizational learning capability as drivers of HAW in a healthcare context. Personnel Review, 46(2), 314-338.

Seligman, M. E. P. (2006). Learned Optimism: How to Change Your Mind and Your Life. Ney York: Vintage Books.

Sessa, V., Kabacoff, R., Deal, J., \& Brown, H. (2007). Research tools for the psychologist-manager: Generational differences in leader values and leadership behaviors. Psychologist-Manager Journal, 10(1), 47-7 4.

Stogdill, R. M. (1948). Personal factors associated with leadership: A survey of the literature. Journal of Psychology, 25, 35-71.

Stogdill, R. M. (1974). Handbook of leadership: A survey of theory and research. New York: Free Press.

Walumbwa, F. O., Hartnell, C. A., \& Oke, A. (2010). Servant leadership, procedural justice climate, service climate, employee attitudes, and organizational citizenship behavior: A cross-level investigation. Journal of Applied Psychology, 95, 517-529.

Wong, N. T., Zimmerman, M. A., \& Parker, E. A. (2010). A typology of youth participation and empowerment for child and adolescent health promotion. American Journal of Community Psychology, 46(1-2), 100-114.

Yin, R. K. (2014). Case study research design and methods. 5th Ed. Thousand Oaks, CA: Sage publications.

Zaccaro, S. J., Kemp, C., \& Bader, P. (2004). Leader traits and attributes. In J. Antonakis, A. T. Cianciolo, \& R. J. Sternberg (Eds.), The nature of leadership (pp. 101-124). Thousand Oaks, CA: Sage. 
INTERNATIONAL JOURNAL OF ACADEMIC RESEARCH IN BUSINESS AND SOCIAL SCIENCES

Vol. 9, No. 11, November, 2019, E-ISSN: 2222-6990 @ 2019 HRMARS

Zacharatos, Barling, \& Kelloway. (2000). Development and effects of transformational leadership in adolescents. Leadership Quarterly, 11(2), 211-226. 